\title{
Enumeration, Isolation and Identification of Diazotrophic Bacteria in Rhizosphere Soil of Two Rice Varieties in Jammu District, India
}

\author{
Harkirat Singh and Renu Gupta*
} Division of Soil Science and Agricultural Chemistry, Faculty of Agriculture, SKUAST-J,
Chatha, Jammu, India

*Corresponding author

\begin{tabular}{l} 
Ke y w o r d s \\
$\begin{array}{l}\text { Enumeration, Nitrogen } \\
\text { fixers, Biochemical tests, } \\
\text { Azotobacter, Beijerinckia, } \\
\text { Characterization, } \\
\text { Identification }\end{array}$ \\
\hline Article Info \\
$\begin{array}{l}\text { Accepted: } \\
17 \text { July } 2018 \\
\text { Available Online: } \\
10 \text { August } 2018\end{array}$
\end{tabular}

Free living diazotrophic bacteria bacteria were isolated from the rhizosphere soil of two cultivated rice varieties grown in R. S. Pura and Bishnah blocks of Jammu district of Jammu Division of J\&K State. Soil samples were collected from rice rhizosphere at panicle initiation stage. A total of twenty rice grown villages were selected and from each village two composite samples were taken from five plants one each from variety Basmati370 and Ratna through random sampling from each rice growing village of R. S. Pura and Bishnah blocks of Jammu district by using GPS. The bacterial isolates characterized by various biochemical tests performed on them were identified by characteristics as outlined in Bergeys Manual of Systematic Bacteriology. The physico chemical properties of the soil were also estimated and correlated with changes in different environmental factors such as soil moisture, pH, EC, OC, N, P, K contents in different areas of R. S. Pura and Bishnah blocks and found to have influenced nitrogen fixation in soil thus affecting nitrogen fixers in the soil. The study highlighted the aerobic and anaerobic nature of isolates based on biochemical tests viz. catalase, nitrate reduction, citrate utilization and oxidase tests performed on them.

\section{Introduction}

Rice is the agricultural crop with the thirdhighest worldwide production after sugarcane and maize (FAO, 2017). As a staple food it is the most widely consumed cereal by a large part of the world's human population, especially in Asia. Nitrogen is major nutrient limiting the high yield potential of modern rice cultivars. Due to the realization of importance of nitrogen in rice farmers have preferred $\mathrm{N}$-fertilizer responsive varieties of rice. Therefore as an alternative to inorganic nitrogen fertilizers free living nitrogen fixing bacteria have been considered for promoting plant growth (Ladha and Reddy, 2000; Park et al., 2004). The demand of nitrogen can therefore be overcome partially by isolating beneficial bacteria due to their potential as biofertlizers (Vessey, 2003).

Basmati-370 and ratna rice varieties are cultivated mainly in two respective blocks of R. S. Pura and Bishnah in Jammu district of J\&K. Nitrogen fixers could be an important component of sustainable agriculture systems. 
The aim of the present research was to isolate, and identify diazotrophic bacteria (free living nitrogen fixers) in rice rhizosphere soil so that they can be characterized for nitrogen fixation to reduce the use of chemical nitrogenous fertilizers.

\section{Materials and Methods}

\section{Soil sampling}

Soil samples were collected from rice rhizosphere at panicle initiation stage. A total of twenty rice grown villages were selected and from each village two composite samples were taken from five plants one each from variety Basmati-370 and Ratna through random sampling from each rice growing village of R.S. Pura and Bishnah blocks of Jammu district by using GPS (Table 1).

A total of twenty rice grown villages were selected and from each village two samples were taken, one from Basmati-370 and other from variety Ratna through random sampling. The location of each village is given in Table 1 .

\section{Dilution of soil samples}

The sampled rhizosphere soil from each site was mixed thoroughly to make a composite soil sample. Ten grams of each soil sample was then diluted to $100 \mathrm{ml}$ to make $10^{-1}$ dilution and further serial dilutions were prepared to $10^{-8}$ dilution under aseptic condition.

\section{Bacterial counts}

The calculation for the total number of bacteria was done by plating soil dilution on nutrient agar medium and total number of nitrogen-fixers was counted by plating soil dilutions on nitrifying medium using plating enrichment and pour plate technique and incubating the plates for $7-10$ days at $30^{\circ} \mathrm{C}$. The total count of the microorganisms was obtained by multiplying the number of cells per plate by the dilution factor

Bacteria/gm soil $=$ Number of bacteria/ Wt. of soil x Dilution

\section{Isolation of diazotrophic bacteria}

Nitrogen fixers viz. Azotobacter and Beijerinckia (Becking, 1981) were isolated on selective medium viz., the total nitrifying population was quantified in Basmati-370 and Ratna variety in rhizosphere soil of rice grown in different areas of Jammu district using nitrifying medium (Lewis and Pramer, 1958)

\section{Microscopic examination and identification of gram staining}

Bacteria was studied for colony and cell morphology following microscopic examination and further identification of gram staining (Gram, 1884).

\section{Biochemical characterization of isolates}

The bacterial isolates were characterized using various biochemical test performed viz. Catalase test, Citrate utilization test, Nitrate reduction test and oxidase test(Cappucino and Sherman,1992).

\section{Identification}

The bacterial isolates characterized by various biochemical tests performed on them were identified by characteristics as outlined in Bergey's Manual of Systematic Bacteriology (vol. 2 revised edition).

\section{Soil physico-chemical properties (Table 2)}

The physico-chemical properties were analyzed as per the procedures outlined below: 
pH

$\mathrm{pH}$ of the soil samples was determined in 1:2.5 soil: water ratio (w/v) with the help of glass electrode $\mathrm{pH}$ meter (Jackson, 1973).

\section{Electrical conductivity}

Electrical conductivity was estimated in 1:2.5 soil: water suspension with EC meter as given by Jackson (1973).

\section{Organic carbon}

Organic carbon was analyzed with the help of Rapid titration method as proposed by Walkley and Black (1934).

\section{Moisture}

Moisture content was determined by gravimetric method as given by Black C. A. (1965).

\section{Texture}

Textural class was determined by Hydrometer method as given by Piper (1966).

\section{Nutrient status of the soil samples}

The nutrient status of the soil samples were analyzed as per the following method:

\section{Available nitrogen}

Nitrogen was determined by using alkaline permanganate as per the modified Kjeldahl method proposed by Subbiah and Asija (1956).

\section{Available phosphorus}

The available phosphorus was determined by the method mentioned by Olsen et al., (1954).

\section{Available potassium}

$1 \mathrm{~N}$ ammonium acetate was used as extractant and the available potassium content was determined by feeding the extract to flame photometer (Jackson, 1973).

\section{Results and Discussion}

\section{Enumeration of total biomass and $\mathrm{N}$-fixers in Jammu district}

Our study revealed that total number of $\mathrm{N}$ fixers and percentage of $\mathrm{N}$-fixers using nitrifying medium was more in R. S. Pura as compared to Bishnah block (Table 2).

Bacterial morphology of Diazotrophic bacterial isolates in Jammu district

The appearance of the colonies of Azotobacter bacteria grown on selective medium were circular, raised in elevation, small and pin type in size and creamy white in colour. Beijerinckia colonies on selective medium were irregular, flat in elevation and small in size and white in colour. Bacterial colonies raised on nutrient agar medium were pinpoint in size, circular in elevation, round and offwhite in colour (Table 3) these result are in conformity with those of Khan et al., (2008)

\section{Biochemical characterization of bacterial isolates in Jammu district}

Gram negative bacteria were more predominant than gram positive in the rhizosphere soil of Basmati-370 and Ratna rice. In our study, majority of bacteria were gram negative which suggests that Azotobacter and Pseudomonas may be predominant in the rhizosphere. These results are in agreement with Bowen and Foster, (1978) and Lilinares et al., (1994) who stated that the abundance of Azotobacter and Pseudomonas may be due to the existence of 
more favorable environmental conditions for their growth and their ability to efficiently use nutrients provided to plants in the form of exudates and produce substances that inhibit the growth of other microorganisms in their vicinity.

All diazotrophic bacterial isolates (Azotobacter) obtained from rhizosphere soil of Basmati-370 (Table 4) and Ratna (Table 6) rice in RS Pura and Bishnah block of Jammu district were rod shaped. The maximum number of diazotrophic bacterial isolates (Beijerinckia) was rod shaped in Basmati-370 rhizosphere (Table 5).

The maximum no. of diazotrophic bacterial isolates (Beijerinckia) in Ratna rhizosphere (Table 7) were rod shaped followed by rod shaped and mature dumbbell shaped cells in soil sample number twelve, thirteen, fifteen and seventeen in Bishnah block. Similar results have been reported by Khan et al., (2008).

Biochemical tests (Catalase, Nitrate reduction, Citrate utilization and Oxidase test) performed on bacterial isolates of diazotrophic bacteria obtained from rhizosphere soil of Basmati-370 and Ratna rice growing areas of RS Pura and Bishnah blocks of Jammu district showed positive results except few, which showed negative results. Catalase test were positive in majority of soil samples tested for diazotrophic bacteria.

Catalase production and activity was detected by adding substrate $\mathrm{H}_{2} \mathrm{O}_{2}$ to bacterial isolates. Organisms which produce enzyme breakdown the $\mathrm{H}_{2} \mathrm{O}_{2}$ and resulting oxygen production produces bubbles in the reagent drop, indicates positive test. Organisms lacking the cytochrome system also lack the catalase enzyme and were unable to breakdown $\mathrm{H}_{2} \mathrm{O}_{2}$ into $\mathrm{H}_{2} \mathrm{O}$ and $\mathrm{O}_{2}$ and were catalase negative. The enzyme was present in most cytochrome containing aerobic and facultative anaerobic bacteria. In the absence of enzyme, the toxic concentration cannot be degraded when these organisms are cultivated in the presence of oxygen (Srivastava, 2013).

In case of nitrate reduction test, in anaerobic conditions bacteria used $\mathrm{NO}_{3}{ }^{-}$as a source of oxygen and reduced to nitrite i.e. nitrate reduction was positive. Our results are in line with the results of Karpagam and Nagalaxmi, (2014). The nitrate reduction confirms that the isolates could reduce nitrate to nitrite but not to nitrogen gas, consistent with their ability to fix nitrogen.

This suggests they are capable of breaking down nitrate containing fertilizers in case of anaerobic conditions in soil. Most bacteria utilize the available oxygen in the medium for their growth and rapidly produced anaerobic conditions for further reaction suggesting that aerobic condition also do prevail in soil sample tested.

Bacteria used citrate as sole source of carbon and nitrogen and give the blue color to medium denoted citrate utilization positive as reported by Panhwar et al., 2012. This indicates that if the test is positive, the $\mathrm{pH}$ is raised and there will be no acid in the end product as reported by Park et al., (2005).

The oxidase test is used to determine if a bacterium produces cytochrome c oxidase. The cytochrome system is usually present in aerobic organisms that are capable of using oxygen as the final hydrogen acceptor. The reagent is dark-blue to maroon in color when oxidized, and colorless when reduced. Maximum isolates of diazotrophic bacteria require aerobic conditions except few of them can grow even in anaerobic conditions as indicated by oxidase test. Similar results are also reported by Karpagam and Nagalakshmi (2014). 
Table.1 Location of the soil samples

\begin{tabular}{|c|c|c|c|}
\hline S. No. & Village & block & GPS Location \\
\hline 1. & Tinda & RS Pura & $32^{\circ} 37^{\prime} 40.662^{\prime \prime} \mathrm{N} 74^{\circ} 47^{\prime} 23.310^{\prime \prime} \mathrm{E}$ \\
\hline 2. & Rattian & RS Pura & 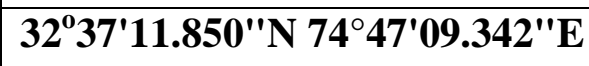 \\
\hline 3. & Kir Pind & RS Pura & $32^{\circ} 37^{\prime} 11.568^{\prime \prime} \mathrm{N} 74^{\circ} 47^{\prime} 09.048^{\prime \prime} \mathrm{E}$ \\
\hline 4. & Mahlawal & RS Pura & $32^{\circ} 37^{\prime} 01.434^{\prime \prime} \mathrm{N} 74^{\circ} 46^{\prime} 50.622^{\prime \prime} \mathrm{E}$ \\
\hline 5. & Tanda & RS Pura & $32^{\circ} 36^{\prime} 46.944^{\prime \prime} \mathrm{N}^{\circ} 4^{\circ} 46^{\prime} 27.630^{\prime \prime} \mathrm{E}$ \\
\hline 6. & Kotli Shah & RS Pura & $32^{\circ} 36^{\prime} 56.796^{\prime \prime} \mathrm{N}^{\circ} 4^{\circ} 46^{\prime} 06.198^{\prime \prime} \mathrm{E}$ \\
\hline 7. & Mahlawal & RS Pura & $32^{\circ} 37^{\prime} 03.300^{\prime \prime} \mathrm{N} 74^{\circ} 45^{\prime} 52.020^{\prime \prime} \mathrm{E}$ \\
\hline 8. & Tikrian & RS Pura & $32^{\circ} 37^{\prime} 19.884^{\prime \prime} \mathrm{N} 74^{\circ} 44^{\prime} 43.182^{\prime \prime} \mathrm{E}$ \\
\hline 9. & Banota & RS Pura & $32^{\circ} 37^{\prime} 19.734^{\prime \prime} \mathrm{N} 74^{\circ} 44^{\prime} 41.988^{\prime \prime} \mathrm{E}$ \\
\hline 10. & Langarwal & RS Pura & $32^{\circ} 37^{\prime} 16.992^{\prime \prime} \mathrm{N} 74^{\circ} 42^{\prime} 27.378^{\prime \prime} \mathrm{E}$ \\
\hline 11. & Kulle & Bishnah & $32^{\circ} 37^{\prime} 13.914^{\prime \prime} \mathrm{N} 74^{\circ} 50^{\prime} 40.410^{\prime \prime} \mathrm{E}$ \\
\hline 12. & Dhinda & Bishnah & $32^{\circ} 37^{\prime} 06.498^{\prime \prime} \mathrm{N} 74^{\circ} 50^{\prime} 48.810^{\prime \prime} \mathrm{E}$ \\
\hline 13. & Bishnah Tehsil & Bishnah & $32^{\circ} 366^{\prime} 58.716^{\prime \prime} \mathrm{N} 74^{\circ} 50^{\prime} 57.354^{\prime \prime} \mathrm{E}$ \\
\hline 14. & Ban Chak & Bishnah & $32^{\circ} 36{ }^{\prime} 24.256^{\prime \prime} \mathrm{N} 74^{\circ} 52^{\prime} 09.522^{\prime \prime} \mathrm{E}$ \\
\hline 15. & Pante Di Chubbian & Bishnah & $32^{\circ} 36^{\prime} 05.634^{\prime \prime} \mathrm{N} 74^{\circ} 53 ' 13.776$ 'E \\
\hline 16. & Sorer Tokor & Bishnah & $32^{\circ} 35^{\prime} 47.604^{\prime \prime} \mathrm{N} 74^{\circ} 533^{\prime} 34.026^{\prime \prime} \mathrm{E}$ \\
\hline 17. & Chubbian Brahmana & Bishnah & $32^{\circ} 35^{\prime} 44.736^{\prime \prime} \mathrm{N} 74^{\circ} 52^{\prime} 59.346^{\prime \prime} \mathrm{E}$ \\
\hline 18. & Chorli & Bishnah & $32^{\circ} 35^{\prime} 56.058^{\prime \prime} \mathrm{N} 74^{\circ} 52^{\prime} 27.822^{\prime \prime} \mathrm{E}$ \\
\hline 19. & Dabbar & Bishnah & $32^{\circ} 35^{\prime} 39.756^{\prime \prime} \mathrm{N} 74^{\circ} 51^{\prime} 46.266^{\prime \prime} \mathrm{E}$ \\
\hline 20. & Daali & Bishnah & 32 $^{\circ} 35^{\prime} 52.932^{\prime \prime} \mathrm{N} \mathrm{74}^{\circ} 50^{\prime} 07.632^{\prime \prime} \mathrm{E}$ \\
\hline
\end{tabular}


Table.2 Enumeration of total biomass and N-fixers in Jammu district

\begin{tabular}{|c|c|c|c|c|c|c|}
\hline \multirow[t]{2}{*}{ Dilution(x10) } & \multicolumn{2}{|c|}{ Total Biomass } & \multicolumn{2}{|c|}{ Nitrogen fixers } & \multicolumn{2}{|c|}{$\%$ of $\mathrm{N}$-fixer } \\
\hline & R. S. Pura & Bishnah & R. S. Pura & Bishnah & R. S. Pura & Bishnah \\
\hline 1 & 110 & 108 & 33 & 30 & & \\
\hline 2 & 55 & 54 & 24 & 23 & & \\
\hline 3 & 42 & 40 & 20 & 19 & & \\
\hline 4 & 31 & 31 & 15 & 14 & 42.9 & 40.8 \\
\hline 5 & 15 & 15 & 9 & 8 & & \\
\hline 6 & 8 & 7 & 6 & 6 & & \\
\hline 7 & 4 & 5 & 5 & 5 & & \\
\hline 8 & 2 & 1 & 2 & 2 & & \\
\hline Grant total & 266 & 262 & 114 & 107 & & \\
\hline
\end{tabular}

Table.3 Bacterial Morphology of Diazotrophic bacteria in rhizosphere soils in different areas of Jammu District

\begin{tabular}{|l|l|l|l|l|l|l|l|l|}
\hline Medium & Bacteria & Size & Shape & Elevation & Surface & Consistency & pigmentation \\
\hline Becking & Azotobacter & Small & Circular & Raised & Smooth & Viscous & Creamy white \\
\hline Becking & Beijerinckia & Small & Irregular & Flat & Smooth & Viscous & White \\
\hline Nitrifying & N-fixers & Pin head & Small & Circular & Round & Smooth & Off-White \\
\hline
\end{tabular}


Table.4 Characterization of diazotrophic bacteria (Azotobacter) from rhizosphere soil of Basmati-370 rice in different areas of Jammu District

\begin{tabular}{|c|c|c|c|c|c|c|c|}
\hline $\begin{array}{l}\text { Sr. } \\
\text { No. }\end{array}$ & Sample & $\begin{array}{l}\text { Gram } \\
\text { staining }\end{array}$ & $\begin{array}{c}\text { Cell } \\
\text { morphology }\end{array}$ & $\begin{array}{c}\text { Catalase } \\
\text { test }\end{array}$ & $\begin{array}{c}\text { Nitrate } \\
\text { reduction } \\
\text { test }\end{array}$ & $\begin{array}{c}\text { Citrate } \\
\text { utilization } \\
\text { test }\end{array}$ & $\begin{array}{c}\text { Oxidase } \\
\text { test }\end{array}$ \\
\hline 1 & $\mathrm{R} 1$ & - & Rod shaped & + & + & + & + \\
\hline 2 & $\mathrm{R} 2$ & - & Rod shaped & + & + & + & + \\
\hline 3 & R3 & - & Rod shaped & + & + & + & + \\
\hline 4 & $\mathrm{R} 4$ & - & Rod shaped & + & + & + & + \\
\hline 5 & R5 & - & Rod shaped & + & - & - & + \\
\hline 6 & R6 & - & Rod shaped & - & + & + & + \\
\hline 7 & $\mathrm{R} 7$ & - & Rod shaped & + & - & - & + \\
\hline 8 & $\mathrm{R} 8$ & - & Rod shaped & + & + & + & + \\
\hline 9 & R9 & - & Rod shaped & + & - & + & - \\
\hline 10 & $\mathrm{R} 10$ & - & Rod shaped & + & + & + & + \\
\hline 11 & B1 & - & Rod shaped & + & + & + & + \\
\hline 12 & B2 & _ & Rod shaped & - & + & + & - \\
\hline 13 & B3 & - & Rod shaped & + & + & + & + \\
\hline 14 & B4 & - & Rod shaped & + & - & + & - \\
\hline 15 & B5 & - & Rod shaped & + & + & - & + \\
\hline 16 & B6 & - & Rod shaped & - & + & + & + \\
\hline 17 & B7 & - & Rod shaped & - & - & + & + \\
\hline 18 & B8 & - & Rod shaped & + & + & - & + \\
\hline 19 & B9 & - & Rod shaped & - & + & + & + \\
\hline 20 & B10 & - & Rod shaped & + & + & + & + \\
\hline
\end{tabular}

R: I block, B: II block, 1-10: No of villages 
Table.5 Characterization of diazotrophic bacteria (Beijerincka) from rhizosphere soil of Basmati-370 rice in different areas of Jammu District

\begin{tabular}{|c|c|c|c|c|c|c|c|}
\hline $\begin{array}{l}\text { Sr. } \\
\text { No. }\end{array}$ & Sample & $\begin{array}{l}\text { Gram } \\
\text { staining }\end{array}$ & Cell morphology & $\begin{array}{c}\text { Catalase } \\
\text { test }\end{array}$ & $\begin{array}{c}\text { Nitrate } \\
\text { reduction } \\
\text { test }\end{array}$ & $\begin{array}{c}\text { Citrate } \\
\text { utilization } \\
\text { test }\end{array}$ & $\begin{array}{c}\text { Oxidase } \\
\text { test }\end{array}$ \\
\hline 1 & $\mathbf{R} 1$ & - & Rod shaped & + & + & + & + \\
\hline 2 & $\mathbf{R} 2$ & - & Rod shaped & + & + & - & + \\
\hline 3 & $\mathbf{R 3}$ & - & Rod shaped & + & - & + & + \\
\hline 4 & $\mathbf{R} 4$ & - & Rod shaped & + & + & + & + \\
\hline 5 & $\mathbf{R 5}$ & - & Rod shaped & + & + & + & + \\
\hline 6 & R6 & - & Rod shaped & + & + & + & + \\
\hline 7 & $\mathbf{R 7}$ & - & Rod shaped & + & - & - & + \\
\hline 8 & $\mathbf{R 8}$ & - & Rod shaped & + & + & + & - \\
\hline 9 & R9 & - & Rod shaped & + & + & - & + \\
\hline 10 & R10 & - & Rod shaped & - & + & + & + \\
\hline 11 & B1 & - & Rod shaped & + & + & + & + \\
\hline 12 & B2 & - & Rod shaped & - & + & + & + \\
\hline 13 & B3 & - & Rod shaped & + & - & + & + \\
\hline 14 & B4 & - & Rod shaped & + & + & + & + \\
\hline 15 & B5 & - & Rod shaped & + & + & + & + \\
\hline 16 & B6 & - & Rod shaped & - & + & - & - \\
\hline 17 & B7 & - & Rod shaped & + & + & + & + \\
\hline 18 & B8 & - & Rod shaped & + & - & + & - \\
\hline 19 & B9 & - & Rod shaped & + & + & + & - \\
\hline 20 & B10 & - & Rod shaped & - & + & + & + \\
\hline
\end{tabular}


Table.6 Isolation and characterization of diazotrophic bacteria (Azotobacter) from rhizosphere soil of Ratna rice in different areas of Jammu District

\begin{tabular}{|c|c|c|c|c|c|c|c|}
\hline $\begin{array}{l}\text { Sr. } \\
\text { no. }\end{array}$ & Sample & $\begin{array}{l}\text { Gram } \\
\text { staining }\end{array}$ & Cell morphology & $\begin{array}{c}\text { Catalase } \\
\text { test }\end{array}$ & $\begin{array}{c}\text { Nitrate } \\
\text { reduction } \\
\text { test }\end{array}$ & $\begin{array}{c}\text { Citrate } \\
\text { utilization test }\end{array}$ & $\begin{array}{l}\text { Oxidase } \\
\text { test }\end{array}$ \\
\hline 1 & R1 & - & Rod shaped & + & + & + & + \\
\hline 2 & $\mathbf{R} 2$ & - & Rod shaped & - & - & + & + \\
\hline 3 & R3 & - & Rod shaped & + & + & + & + \\
\hline 4 & R4 & - & Rod shaped & + & + & - & + \\
\hline 5 & $\mathbf{R 5}$ & - & Rod shaped & + & - & + & + \\
\hline 6 & R6 & - & Rod shaped & - & + & + & + \\
\hline 7 & R7 & - & Rod shaped & + & - & + & - \\
\hline 8 & $\mathbf{R 8}$ & - & Rod shaped & - & + & + & - \\
\hline 9 & R9 & - & Rod shaped & + & + & + & + \\
\hline 10 & R10 & - & Rod shaped & + & + & + & + \\
\hline 11 & B1 & - & Rod shaped & + & + & - & + \\
\hline 12 & B2 & - & Rod shaped & + & - & + & + \\
\hline 13 & B3 & - & Rod shaped & + & + & + & + \\
\hline 14 & B4 & - & Rod shaped & + & + & + & + \\
\hline 15 & B5 & - & Rod shaped & + & + & + & + \\
\hline 16 & B6 & - & Rod shaped & + & + & + & + \\
\hline 17 & B7 & - & Rod shaped & + & + & + & + \\
\hline 18 & B8 & - & Rod shaped & - & + & + & + \\
\hline 19 & B9 & - & Rod shaped & + & + & - & + \\
\hline 20 & B10 & - & Rod shaped & + & + & - & + \\
\hline
\end{tabular}


Table.7 Isolation and characterization of diazotrophic bacteria (Beijerinckia) from rhizosphere soil of Ratna rice in different areas of Jammu District

\begin{tabular}{|c|c|c|c|c|c|c|c|}
\hline $\begin{array}{l}\text { Sr. } \\
\text { no. }\end{array}$ & Sample & $\begin{array}{l}\text { Gram } \\
\text { staining }\end{array}$ & Cell morphology & $\begin{array}{l}\text { Catalase } \\
\text { test }\end{array}$ & $\begin{array}{l}\text { Nitrate } \\
\text { reduction test }\end{array}$ & $\begin{array}{l}\text { Citrate } \\
\text { utilization test }\end{array}$ & $\begin{array}{l}\text { Oxidase } \\
\text { test }\end{array}$ \\
\hline 1 & R1 & - & Rod shaped & + & + & + & + \\
\hline 2 & $\mathbf{R 2}$ & _- & Rod shaped & + & _- & + & + \\
\hline 3 & $\mathbf{R 3}$ & - & Rod shaped & + & + & + & + \\
\hline 4 & R4 & - & Rod shaped & + & + & _- & + \\
\hline 5 & R5 & - & Rod shaped & + & + & + & + \\
\hline 6 & R6 & _- & Rod shaped & + & + & + & + \\
\hline 7 & R7 & - & Rod shaped & + & + & _- & + \\
\hline 8 & R8 & - & Rod shaped & + & + & + & + \\
\hline 9 & R9 & - & Rod shaped & + & _- & + & _- \\
\hline 10 & R10 & - & Rod shaped & + & + & + & + \\
\hline 11 & B1 & - & Rod shaped & + & + & + & + \\
\hline 12 & B2 & - & $\begin{array}{l}\text { Rod shaped when young, } \\
\text { Dumbbell when mature }\end{array}$ & + & + & + & - \\
\hline 13 & B3 & - & $\begin{array}{l}\text { Rod shaped when young, } \\
\text { Dumbbell when mature }\end{array}$ & - & + & + & + \\
\hline 14 & B4 & _- & Rod shaped & + & + & + & + \\
\hline 15 & B5 & - & $\begin{array}{l}\text { Rod shaped when young, } \\
\text { Dumbbell when mature }\end{array}$ & - & + & - & + \\
\hline 16 & B6 & _- & Rod shaped & + & _- & _- & + \\
\hline 17 & B7 & - & $\begin{array}{l}\text { Rod shaped when young, } \\
\text { Dumbbell when mature }\end{array}$ & + & + & + & + \\
\hline 18 & B8 & _- & Rod shaped & + & + & + & _- \\
\hline 19 & B9 & - & Rod shaped & - & - & + & + \\
\hline 20 & B10 & - & Rod shaped & + & + & + & + \\
\hline
\end{tabular}

Table.8 Physico-chemical properties of the rhizosphere soils of rice in different areas of Jammu district

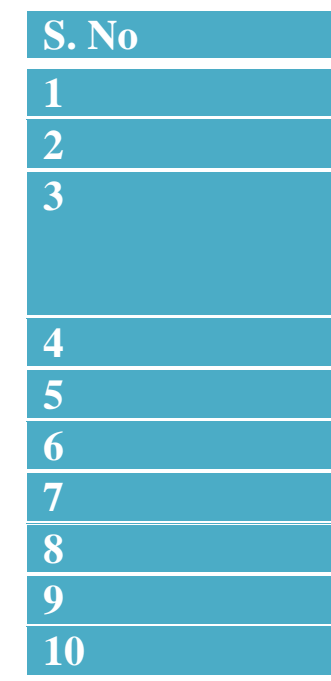

\begin{tabular}{|l|l|l|}
\hline Parameters & Basmati-370 & Ratna \\
\hline Sampling depth & $0-15$ & $0-15$ \\
\hline Moisture \% & $15.47 \pm 1.96^{*}$ & $14.40 \pm 2.61$ \\
\hline Particle sizes & 32.26 & 35.86 \\
Clay & 27.78 & 27.64 \\
Silt & 38.88 & 36.48 \\
\hline Textural class & Clay loam & Clay loam \\
\hline pH & $6.97 \pm 0.37^{*}$ & $6.90 \pm 0.34$ \\
\hline EC & $0.30 \pm 0.07^{*}$ & $0.28 \pm 0.04$ \\
\hline OC & $0.60 \pm 0.06^{*}$ & $0.58 \pm 0.04$ \\
\hline Available N & $159.6 \pm 27.91^{*}$ & $171.8 \pm 25.24$ \\
\hline Available P & $6.97 \pm 0.84^{*}$ & $7.05 \pm 0.72$ \\
\hline Available k & $75.6 \pm 17.19^{*}$ & $70.8 \pm 12.93$ \\
\hline
\end{tabular}

$*_{ \pm \text {indicates } S . D \text { values }}$ 


\section{Physico-chemical properties}

The $\mathrm{pH}$ of soils varied from slightly acidic to neutral. The $\mathrm{pH}$ of rhizosphere soil of Basmati370 rice ranged from 6.28 to 7.50 having mean value of 6.97 whereas Ratna rice soils had a mean value of 6.90 in Jammu di strict (RS Pura and Bishnah blocks).The Electrical conductivity (EC) of rhizosphere soil ranged from 0.14 to $0.41 \mathrm{dS} \mathrm{m}^{-1}$ in Basmati-370 and 0.22 to 0.38 $\mathrm{dSm}^{-1}$ in Ratna rice respectively. These values are in safe range for rice cultivation. The organic carbon content lied in medium range. Organic carbon content of soils in Basmati-370 and Ratna ranged from 0.51 to $0.72(\%)$ and 0.51 to $0.65(\%)$, respectively. Highest organic carbon $0.72 \%$ was recorded at Kotli Shah Village. The moisture content of rhizosphere soil lied between 11.94 to $19.66 \%$ in Basmati370 soils and 9.8 to $17.72 \%$ in Ratna rice. The dominant soil textural class was clay loam. The clay content of rhizosphere soil ranged from 18.8 to $50.0 \%$, silt content ranged from 14.7 to $36.5 \%$ and sand content ranged from 25.1 to $49.2 \%$ in Basmati-370 rice. In rhizosphere soils of Ratna clay content ranged from 26.3 to 49.2 $\%$, silt content ranged from 18.2 to $36.3 \%$ and sand content varied from 14.5 to $46.6 \%$.

The available nitrogen content of soil in rice rhizosphere of Jammu district (RS Pura and Bishnah blocks) is in medium range. The available nitrogen in rhizosphere soil ranged from 129.2 to $212.2 \mathrm{mg} \mathrm{kg}^{-1}$ with mean value $159.6 \mathrm{mg} \mathrm{kg}^{-1}$ in Basmati-370, whereas it ranged from 129.4 to $221.7 \mathrm{mg} \mathrm{kg}^{-1}$ with mean value $171.8 \mathrm{mg} \mathrm{kg}^{-1}$ in Ratna rice of Jammu district. The available phosphorus content in rhizosphere soil ranged from 6.02 to $8.76 \mathrm{mg}$ $\mathrm{kg}^{-1}$ with the mean value of $6.97 \mathrm{mg} \mathrm{kg}^{-1}$ in Basmati-370 and it ranged from 6.21 to $8.56 \mathrm{mg}$ $\mathrm{kg}^{-1}$ with the mean value $7.05 \mathrm{mg} \mathrm{kg}^{-1}$ in Ratna rice. Phosphorus content in rice soils fell in medium range. The available potassium content in rhizosphere soil ranged from 60.5 to 105.1 $\mathrm{mg} \mathrm{kg}^{-1}$ with the mean value of $75.6 \mathrm{mg} \mathrm{kg}^{-1}$ in Basmati-370, while it ranged from 60.5 to 93.5 $\mathrm{mg} \mathrm{kg}{ }^{-1}$ with the mean value of $70.8 \mathrm{mg} \mathrm{kg}^{-1}$ under Ratna rice of Jammu district (RS Pura and Bishnah). The potassium content lies between low to medium range. The mean values of physico-chemical parameters are presented in (Table 8).

The presence of Nitrogen fixers in rhizosphere soils of basmati-370 rice variety highlighted increased nitrogen availability in the soil to fix atmospheric nitrogen. Changes in different environmental factors such as soil moisture, $\mathrm{pH}$, $\mathrm{EC}, \mathrm{OC}, \mathrm{N}, \mathrm{P}, \mathrm{K}$ contents in different areas of R. S. Pura and Bishnah blocks have influenced nitrogen fixation in soil thus affecting nitrogen fixers in the soil. The study highlighted the aerobic and anaerobic nature of isolates based on biochemical tests viz. catalase, nitrate reduction, citrate utilization and oxidase tests performed on them.

\section{Acknowledgements}

Authors are thankful to the Head, Division of Soil Sciences and Agricultural Chemistry, SKUAST-J, Jammu and Director, Centre for Biodiversity Studies, BGSBU, Rajouri for providing necessary facilities to carry out this piece of research.

\section{References}

Beck, M. A. and Sanchez, P. A. 1994. Soil phosphorus fraction dynamics during 18 years of cultivation on a Typic Paleudult. Soil Science. 34: 1424 - 14.

Becking, J. H. 1981. The family Azotobacteraceae. In: The Prokaryotes. A hand book on habitats, isolation and identification of bacteria. SpringerVerlag, Berlin. I, pp 795-877

Bowen, G. D. and Foster, R. C. 1978. Isolation, screening of growth promoting and diversity of rhizobacteria from vetiver grass and rice plants. Thailand Journal of Agricultural Science 43: 217-230.

Cappuccino, J. G. and Sherman, N. 1992. Biochemical activities of microorganisms. Microbiology, a laboratory manual (1st ed.), The Benjamin/Cummings Publishing Co, California, pp. 105-300. 
Gram, C. 1884. Ueber die isolirte Firbung der Schizomyceten iu Schnitt-und Trockenpriparaten. Fortschitte der Medicin, Vol. 2, pp 185-189.

Jackson, N. L. 1973. Soil Chemical Analysis. Prentice Hall, India Pvt. Ltd. New Delhi, pp. 56-70.

Karpagam, T. and Nagalaxmi, P. K. 2014. Isolation of phosphate solubilizing microbes from Agricultural soil. International Journal of Current Microbiology and Applied Sciences 3 (3): 601-614.

Khan, M. H. R., Mohiuddin, M. and Rahman, M. 2008. Enumerization, isolation and identification of nitrogen-fixing bacterial strains at seedling stage in rhizosphere of rice grown in non-calcareous grey flood plain soil of Bangladesh. Journal of the Faculty of Environment Science and Technology 13 (1): 97-101.

Ladha, J.K., and Reddy, P.M. 2000. The quest for nitrogen fixation in rice. Proceedings of the Third Working Group Meeting on Assessing Opportunities for Nitrogen Fixation in Rice, 9â€"12 Aug. 1999, IRRI, Los Banos, Laguna, Philippines, 354

Lewis, R. F. and. Pramer, D. 1958. Isolation of Nitrosomonas in pure culture.Journal of Bacteriology. 76(5): 524-528.

Lilinares, F., Munoz-Mingarro, D., Pozuelo, J. M., Ramos, B. and Bermudez de Castro, F. 1994. Microbial inhibition and nitrification potential in soils incubated with Elaeagnus angustifolia L leaf litter. Geomicrobiology Journal 11: 149-56.

Olsen, S. R., Cole, C. V., Watanabe, F. S. and Dean, A.L. 1954. Estimation of available phosphorus in soils by extraction with sodium biocarbonate USDA. Hrc. p. 939.
Panhwar, Q. A., Othman, R., Rahman, Z. A., Meon, S. and Ismail, M. R. 2012. Isolation and characterization of phosphate-solubilizing bacteria from aerobic rice. African Journal of Biotechnology 11 (11): 2711-2719.

Park, M., Kim, C., Yang, J., Lee, H., Shin, W., Kim, S., and Sa, T. 2005. Isolation and characterization of diazotrophic growth promoting bacteria from rhizosphere of agricultural crops of Korea. Microbiological Research 160(2), 12733.

Piper, C. S. 1966. Soil and Plant Analysis..A' Laboratory Manual of Methods for the Examination of Soils and the Determination of the Inorganic Constituents of Plants. HANS PU.B LI S HER S BOMBAY.

Shrivastava, U. P. 2013. Isolation and characterization of diazotrophic plant growth promoting rhizobacteria. International journal of pharmacy \& life sciences 4 (3): 2481-2488.

Subbiah, B.V. and Asija, G.L.1956. A rapid procedure for the determination of available nitrogen in soil, Curr. Sci., 25: 259-260.

UN Food and Agriculture Organization, Corporate Statistical Database (FAOSTAT). 2017. Retrieved May 11, 2011

Vessey, J.K. 2003. Plant Growth Promoting Rhizobacteria as Biofertilizers. Plant and Soil 255: 571-586.

Walkley, A. and I. A. Black. 1934. An examination of Degtjareff method for determining soil organic matter and a proposed modification of the chromic acid titration method. Soil Science 37: 2937.

\section{How to cite this article:}

Harkirat Singh and Renu Gupta. 2018. Enumeration, Isolation and Identification of Diazotrophic Bacteria in Rhizosphere Soil of Two Rice Varieties in Jammu District, India. Int.J.Curr.Microbiol.App.Sci. 7(08): 3041-3052. doi: https://doi.org/10.20546/ijcmas.2018.708.324 